\title{
New-onset pediatric nephrotic syndrome following Pfizer-BioNTech SARS-CoV-2 vaccination: a case report and literature review
}

\author{
Eriko Nakazawa ${ }^{1} \cdot$ Toru Uchimura $^{1} \cdot$ Yuji Hirai ${ }^{1} \cdot$ Hayato Togashi $^{1} \cdot$ Yoshitaka Oyama $^{1} \cdot$ Aya Inaba $^{1} \cdot$ Kentaro Shiga $^{1}$. \\ Shuichi Ito
}

Received: 22 September 2021 / Accepted: 22 October 2021 / Published online: 15 November 2021

(C) Japanese Society of Nephrology 2021

\begin{abstract}
Various new vaccines against severe acute respiratory syndrome coronavirus 2 (SARS-CoV-2) have been rapidly developed. The new onset and recurrence of nephrotic syndrome triggered by some vaccines have been documented and several adult cases of minimal change nephrotic syndrome newly developing after SARS-CoV-2 vaccination have been reported. However, no reports of pediatric cases have been published. Indications for SARS-CoV-2 vaccines have been expanded to those as young as 12 years old and vaccination of children has just started in Japan. We encountered a 15-year-old boy without underlying disease who newly developed nephrotic syndrome after SARS-CoV-2 vaccination with BNT162b2 (Pfizer-BioNTech). He developed eyelid edema 4 days after vaccination and peripheral edema of the lower extremities a further 4 days later. Twenty-one days after vaccination, $60 \mathrm{mg}$ of oral daily prednisolone was started. He achieved complete remission in 12 days without complications such as hypertension or acute kidney injury. We clinicians should be aware of the possibility of nephrotic syndrome developing after SARS-CoV-2 vaccination, not only in adults, but also in children.
\end{abstract}

Keywords SARS-CoV-2 $\cdot$ COVID-19 $\cdot$ Vaccine $\cdot$ Nephrotic syndrome $\cdot$ Child $\cdot$ Trigger

\section{Introduction}

As the severe acute respiratory syndrome coronavirus 2 (SARS-CoV-2) pandemic continues to progress, various new vaccines have been rapidly developed and are expected to be effective in limiting transmission and mortality, particularly as new technologies such as viral vector vaccines and messenger RNA (mRNA) vaccines are being introduced. Evidence of the short- to medium-term efficacy and safety of vaccines is accumulating. Although rare, these new vaccines have side effects such as thrombosis with thrombocytopenia syndrome and myocardial damage $[1,2]$. Recurrence of nephrotic syndrome triggered by a SARS-CoV-2 vaccine has been reported [3]. Additionally, several cases of nephrotic syndrome, mostly minimal change disease (MCD),

Toru Uchimura

toru@yokohama-cu.ac.jp

1 Department of Pediatrics, Yokohama City University Medical Center, 4-57 Urafune-cho, Minami-ku, Yokohama, Kanagawa 232-0024, Japan

2 Department of Pediatrics, Graduate School of Medicine, Yokohama City University, Yokohama, Kanagawa, Japan have been reported in adults after SARS-CoV-2 vaccination [3-10]. Hypertension and acute kidney injury (AKI) are present at high frequencies among these adult cases. Here, we report the case of a 15-year-old boy who newly developed nephrotic syndrome after initial vaccination with BNT162b2 (COMIRNATY ${ }^{\circledR}$, Pfizer-BioNTech). This is the first pediatric case of new-onset nephrotic syndrome following SARSCoV-2 vaccination.

\section{Case report}

A 15-year-old boy with no underlying medical condition, no previous abnormalities noted in school urinalysis, and no known allergies had received the first dose of BNT162b2. The following day, he developed a fever of $37.3^{\circ} \mathrm{C}$ and slight swelling at the injection site. He developed eyelid edema 4 days after vaccination and peripheral edema of the lower extremities on day 8 post-vaccination. He visited the local clinic 16 days after vaccination, urinalysis showed urine protein $4+$, and nephrotic syndrome was suspected. He was referred to our hospital on day 19 post-vaccination. 
His body weight had increased from 45 to $49.7 \mathrm{~kg}$, blood pressure was $106 / 62 \mathrm{mmHg}$, and pulse rate was 69 beats/min. Physical examination showed edema of the eyelids and lower extremities, and the abdomen was distended. Blood tests showed serum albumin $1.6 \mathrm{~g} / \mathrm{dL}$, creatinine $0.64 \mathrm{mg} / \mathrm{dL}$, estimated glomerular filtration rate (eGFR) $116.62 \mathrm{ml} / \mathrm{min} / 1.73 \mathrm{~m}^{2}$, blood urine nitrogen $7 \mathrm{mg} / \mathrm{dL}$, serum sodium $141 \mathrm{mEq} / \mathrm{L}$, potassium $3.9 \mathrm{mEq} / \mathrm{L}$, chloride $106 \mathrm{mEq} / \mathrm{L}$, and total cholesterol $335 \mathrm{mg} / \mathrm{dL}$. Complement $\mathrm{C} 3$ and $\mathrm{C} 4$ were within normal limits. Urinalysis showed urine protein $4+$, urine sediment red blood cells $<1 /$ highpower field, and initial urinary protein-creatinine ratio $7.71 \mathrm{~g} / \mathrm{g}$ creatinine. The result of an anti-SARS-CoV-2 $\mathrm{S}$ serology assay was $111 \mathrm{U} / \mathrm{mL}$ (positive $\geq 0.8 \mathrm{U} / \mathrm{mL}$, Elecsys ${ }^{\circledR}$ ), which is specific for receptor binding domain lesion of SARS-CoV-2 spike protein in human serum and plasma. Laboratory findings on admission are listed in Table 1. Chest X-ray showed bilateral pleural effusions, and ultrasonography showed normal kidney size, but also edema of the intestinal wall and ascites. He was diagnosed with nephrotic syndrome and $60 \mathrm{mg}$ of daily prednisolone (PSL) was initiated, in accordance with the Japanese guidelines for pediatric nephrotic syndrome, at 21 days post-vaccination. The patient achieved complete remission on the 12th day of treatment and did not develop complications such as hypertension, AKI, or thrombus formation.

\section{Discussion}

BNT162b2 is an mRNA-based vaccine encoding the SARSCoV-2 full-length spike protein. Clinical trials of BNT162b2 in 12- to 15-year-olds showed a favorable safety and side effect profile with mainly mild transient reactions such as injection-site pain, fatigue, and headache. Additionally, there were no differences in serious vaccine-related adverse events and severe adverse events compared with those in 16- to 25-year-olds [11]. No new-onset nephrotic syndrome was reported in the pediatric and young adult clinical trials.

We encountered a 15 -year-old boy who newly developed nephrotic syndrome 4 days after the first dose of BNT162b2. As he had no history of infectious disease or other vaccinations during several months prior to the onset of nephrotic syndrome, BNT162b2 vaccination may have triggered the onset of nephrotic syndrome.

The pathogenesis of nephrotic syndrome remains to be elucidated, but it is thought to result from complex interactions among $\mathrm{T}$ cells, B cells, circulating factors, and podocytes [12]. Vaccines would induce systemic immune activation in addition to virus-specific immune responses, and there have been sporadic reports of the new onset of nephrotic syndrome after vaccination against influenza virus, hepatitis B, pneumococcus, smallpox, and measles [13-21]. BNT162b2 vaccination induces a broad immune response with SARS-CoV-2 S-specific neutralizing antibodies, poly-specific $\mathrm{CD}^{+}$and $\mathrm{CD}^{+} \mathrm{T}$ cells, and various
Table 1 Laboratory data on admission

\begin{tabular}{llll}
\hline $\begin{array}{l}\text { Complete blood cell count } \\
\text { White blood cells }(/ \mu \mathrm{L})\end{array}$ & 5420 & Serum chemistry & \\
Red blood cells $\left(\times 10^{4} / \mu \mathrm{L}\right)$ & 568 & Total protein $(\mathrm{g} / \mathrm{dL})$ & 4.3 \\
Hemoglobin $(\mathrm{g} / \mathrm{dL})$ & 16.9 & Blood urine nitrogen $(\mathrm{mg} / \mathrm{dL})$ & 1.6 \\
Hematocrit $(\%)$ & 50.1 & Uric acid $(\mathrm{mg} / \mathrm{dL})$ & 7 \\
Platelets $\left(\times 10^{4} / \mu \mathrm{L}\right)$ & 24.6 & Creatinine $(\mathrm{mg} / \mathrm{dL})$ & 5.8 \\
Coagulation & & Sodium $(\mathrm{mEq} / \mathrm{L})$ & 0.64 \\
PT $(\mathrm{s})$ & 8.7 & Potassium $(\mathrm{mEq} / \mathrm{L})$ & 141 \\
APTT $(\mathrm{s})$ & 30.4 & Chloride $(\mathrm{mEq} / \mathrm{L})$ & 3.9 \\
D-dimer $(\mu \mathrm{g} / \mathrm{mL})$ & 5.6 & Total cholesterol $(\mathrm{mg} / \mathrm{dL})$ & 106 \\
Urinalysis & & C-reactive protein $(\mathrm{mg} / \mathrm{dL})$ & 335 \\
pH & 6.5 & IgG $(\mathrm{mg} / \mathrm{dL})$ & 0.042 \\
Specific gravity & 1.018 & IgA $(\mathrm{mg} / \mathrm{dL})$ & 458 \\
Protein $(\mathrm{g} / \mathrm{g} \bullet \mathrm{cre})$ & 7.71 & IgM $(\mathrm{mg} / \mathrm{dL})$ & 122 \\
$\beta 2-$-microglobulin $(\mathrm{ng} / \mathrm{mL})$ & 159 & Complement $(\mathrm{U} / \mathrm{mL})$ & 154 \\
Urine sediment & & $\mathrm{C} 3(\mathrm{mg} / \mathrm{dL})$ & 57.9 \\
Red blood cells $(/ \mathrm{HPF})$ & $1-4$ & $\mathrm{C} 4(\mathrm{mg} / \mathrm{dL})$ & 141 \\
White blood cells $(/ \mathrm{HPF})$ & $1-4$ & $\mathrm{SARS}-\mathrm{CoV}-2 \mathrm{~S}$ antibody $(\mathrm{U} / \mathrm{mL})$ & 29 \\
\hline
\end{tabular}

$P T$ prothrombin; APTT activated partial thromboplastin time; cre creatinine; $H P F$ high-power field; $I g G$ immunoglobulin G; $I g A$ immunoglobulin A; $I g M$ immunoglobulin $\mathrm{M}$; $S A R S-C o V$-2 severe acute respiratory syndrome coronavirus; $S$ spike

${ }^{\text {a }}$ This was measured with Elecsys ${ }^{\circledR}$ Anti-SARS-CoV-2 


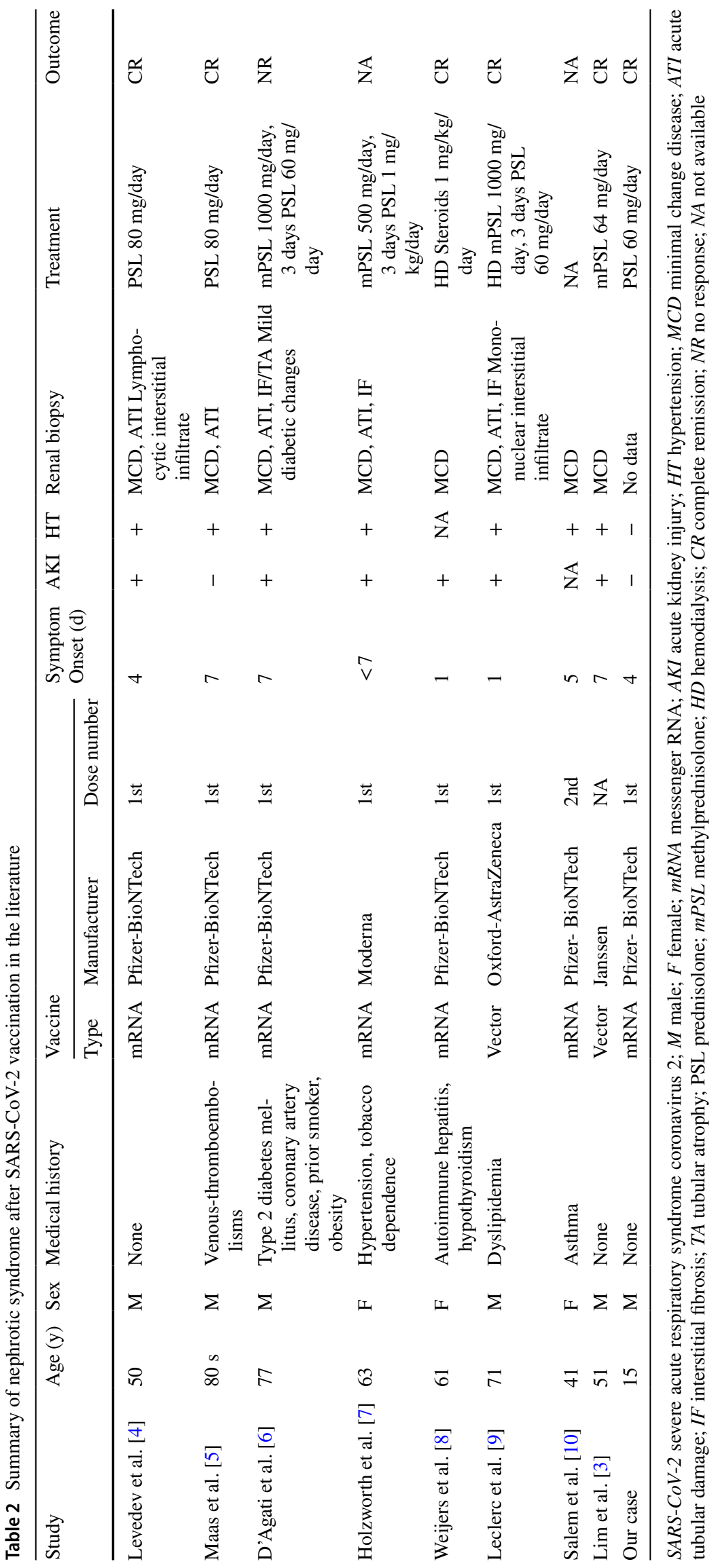


cytokines such as IFN- $\gamma$ and IL-2 [22]. Although these immune responses are assumed to be involved in the development of nephrotic syndrome after SARS-CoV-2 vaccination, we cannot prove a causal relationship between vaccination and the development of nephrotic syndrome because we only have the fact that the patients developed nephrotic syndrome after SARS-CoV-2 vaccination, which is a limitation of this study.

In our search of the literature, we found eight adult cases of new-onset nephrotic syndrome, mostly MCD, after SARS-CoV-2 vaccination (Table 2) [3-10]. Six patients had received mRNA vaccines (five had received BNT162b2) and two had received vector vaccines. Six patients developed nephrotic syndrome after the first SARS-CoV-2 vaccination, one patient after the second vaccination, and in one case the number of vaccinations was not mentioned. All eight adult cases and our case developed symptoms within 1 week of vaccination. With conventional inactivated and live vaccines, the time from vaccination to the onset of nephrotic syndrome is 4 days to several weeks [13-21], so the short time to onset may be a characteristic of the SARS-CoV-2 vaccines being mRNA and vector vaccines. Six adult cases developed AKI and seven had hypertension. All six patients who developed AKI reported in the literature were over the age of 50 years, which may have contributed to the high frequency of AKI. Meanwhile, in a nationwide survey of pediatric nephrotic syndrome in Japan, $24 \%$ of patients show AKI at first presentation [23], but our patient did not develop this complication.

All eight adult cases of post-SARS-CoV-2 vaccination new-onset nephrotic syndrome presented with MCD on renal pathology. Five had acute tubular damage and two had inflammatory cell infiltration into the interstitium. Generally, idiopathic nephrotic syndrome in children is mostly MCD [23]. Conversely, nephrotic syndrome in adults often includes membranous nephropathy [24]. Therefore, the findings that all adult patients had MCD is unique. Steroid therapy was used in all adult cases, but two required hemodialysis for oliguria and diuretic-resistant fluid overload, hyperkalemia, and hyperuricemia. Five patients achieved complete remission, one was refractory to treatment, and two patients had no treatment response noted. Our patient was treated with PSL without renal biopsy in accordance with Japanese guidelines, and we diagnosed him as probably having MCD because he was in complete remission by day 12 .

Vaccination is considered to be the most promising way out of the current global SARS-CoV-2 outbreak, and this strategy will continue to be promoted around the world. We, as healthcare professionals, need to be aware of the possibility of the development of serious side effects such as nephrotic syndrome in adults, but also in children, after SARS-CoV-2 vaccination.
Acknowledgements The authors thank Gillian Campbell, PhD, from Edanz (https://www.jp.edanz.com/ac) for editing a draft of this manuscript.

\section{Declarations}

Conflict of interest The authors declare that there are no conflicts of interest.

Ethical approval This article does not describe any studies with human participants or animals performed by any of the authors.

Informed consent Informed consent was obtained from the patient and his parents for publication of this case report.

\section{References}

1. Greinacher A, Thiele T, Warkentin TE, Weisser K, Kyrle PA, Eichinger S. Thrombotic thrombocytopenia after ChAdOx $1 \mathrm{nCov}-$ 19 vaccination. N Engl J Med. 2021;384:2092-101.

2. Abu Mouch S, Roguin A, Hellou E, Ishai A, Shosan U, Mahamid L, Zoabi M, Aisman M, Goldschmid N, Berar YN. Myocarditis following COVID-19 mRNA vaccination. Vaccine. 2021;39:3790-3.

3. Lim JH, Han MH, Kim YJ, Kim MS, Jung HY, Choi JY, Cho JH, Kim CD, Kim YL, Park SH. New-onset nephrotic syndrome after Janssen COVID-19 vaccination: a case report and literature review. J Korean Med Sci. 2021. https://doi.org/10.3346/jkms. 2021.36.e218.

4. Lebedev L, Sapojnikov M, Wechsler A, Varadi-Levi R, Zamir D, Tobar A, Levin-Iaina N, Fytlovich S, Yagil Y. Minimal change disease following the Pfizer-BioNTech COVID-19 vaccine. Am J Kidney Dis. 2021;78:142-5.

5. Maas RJ, Gianotten S, van der Meijden WAG. An additional case of minimal change disease following the Pfizer-BioNTech COVID-19 vaccine. Am J Kidney Dis. 2021;78:312.

6. D'Agati VD, Kudose S, Bomback AS, Adamidis A, Tartini A. Minimal change disease and acute kidney injury following the Pfizer-BioNTech COVID-19 vaccine. Kidney Int. 2021;100:461-3.

7. Holzworth A, Couchot P, Cruz-Knight W, Brucculeri M. Minimal change disease following the Moderna mRNA-1273 SARS-CoV-2 vaccine. Kidney Int. 2021;100:463-4.

8. Weijers J, Alvarez C, Hermans MMH. Post-vaccinal minimal change disease. Kidney Int. 2021;100:459-61.

9. Leclerc S, Royal V, Lamarche C, Laurin LP. Minimal change disease with severe acute kidney injury following the OxfordAstraZeneca COVID-19 vaccine: a case report. Am J Kidney Dis. 2021. https://doi.org/10.1053/j.ajkd.2021.06.008.

10. Salem F, Rein JL, Yu SM, Abramson M, Cravedi P, Chung M. Report of three cases of minimal change disease following the second dose of mRNA SARS-CoV-2 COVID-19 vaccine. Kidney Int Rep. 2021;6:2523-4.

11. Frenck RW Jr, Klein NP, Kitchin N, Gurtman A, Absalon J, Lockhart S, Perez JL, Walter EB, Senders S, Bailey R, Swanson KA, Ma H, Xu X, Koury K, Kalina WV, Cooper D, Jennings T, Brandon DM, Thomas SJ, Türeci Ö, Tresnan DB, Mather S, Dormitzer PR, Şahin U, Jansen KU, Gruber WC. Safety, immunogenicity, and efficacy of the BNT162b2 Covid-19 vaccine in adolescents. N Engl J Med. 2021;385:239-50.

12. Colucci M, Corpetti G, Emma F, Vivarelli M. Immunology of idiopathic nephrotic syndrome. Pediatr Nephrol. 2018;33:573-84. 
13. Patel C, Shah HH. Vaccine-associated kidney diseases: a narrative review of the literature. Saudi J Kidney Dis Transpl. 2019;30:1002-9.

14. Kielstein JT, Termühlen L, Sohn J, Kliem V. Minimal change nephrotic syndrome in a 65 -year-old patient following influenza vaccination. Clin Nephrol. 2000;54:246-8.

15. Kao CD, Chen JT, Lin KP, Shan DE, Wu ZA, Liao KK. Guillain-Barré syndrome coexisting with pericarditis or nephrotic syndrome after influenza vaccination. Clin Neurol Neurosurg. 2004; 106:136-8.

16. Gutiérrez S, Dotto B, Petiti JP, De Paul AL, Dionisio de Cabalier ME, Torres AI, Mukdsi JH. Minimal change disease following influenza vaccination and acute renal failure: just a coincidence? Nefrologia. 2012;32:414-5.

17. Kutlucan A, Gonen I, Yildizhan E, Aydin Y, Sav T, Yildirim U. Can influenza H1N1 vaccination lead to the membranous glomerulonephritis? Indian J Pathol Microbiol. 2012;55:239-41.

18. Ozdemir S, Bakkaloğlu A, Oran O. Nephrotic syndrome associated with recombinant hepatitis B vaccination: a causal relationship or just a mere association? Nephrol Dial Transplant. 1998;13:1888-9.

19. Kikuchi Y, Imakiire T, Hyodo T, Higashi K, Henmi N, Suzuki S, Miura S. Minimal change nephrotic syndrome, lymphadenopathy and hyperimmunoglobulinemia after immunization with a pneumococcal vaccine. Clin Nephrol. 2002;58:68-72.

20. Clajus C, Spiegel J, Bröcker V, Chatzikyrkou C, Kielstein JT. Minimal change nephrotic syndrome in an 82 year old patient following a tetanus-diphteria-poliomyelitis-vaccination. BMC Nephrol. 2009;10:21.

21. Kuzemko JA. Measles vaccination and the nephrotic syndrome. Br Med J. 1972;4:665-6.

22. Sahin U, Muik A, Vogler I, Derhovanessian E, Kranz LM, Vormehr M, Quandt J, Bidmon N, Ulges A, Baum A, Pascal KE,
Maurus D, Brachtendorf S, Lörks V, Sikorski J, Koch P, Hilker R, Becker D, Eller AK, Grützner J, Tonigold M, Boesler C, Rosenbaum C, Heesen L, Kühnle MC, Poran A, Dong JZ, Luxemburger U, Kemmer-Brück A, Langer D, Bexon M, Bolte S, Palanche T, Schultz A, Baumann S, Mahiny AJ, Boros G, Reinholz J, Szabó GT, Karikó K, Shi PY, Fontes-Garfias C, Perez JL, Cutler M, Cooper D, Kyratsous CA, Dormitzer PR, Jansen KU, Türeci Ö. BNT162b2 vaccine induces neutralizing antibodies and polyspecific T cells in humans. Nature. 2021;595:572-7.

23. Sato M, Ishikura K, Ando T, Kikunaga K, Terano C, Hamada R, Ishimori S, Hamasaki Y, Araki Y, Gotoh Y, Nakanishi K, Nakazato H, Matsuyama T, Iijima K, Yoshikawa N, Ito S, Honda M, Japanese Pediatric Survey Holding Information of Nephrotic Syndrome (JP-SHINE) study of the Japanese Study Group of Renal Disease in Children. Prognosis and acute complications at the first onset of idiopathic nephrotic syndrome in children: a nationwide survey in Japan (JP-SHINE study). Nephrol Dial Transplant. 2021;36:475-81.

24. Yokoyama H, Taguchi T, Sugiyama H, Sato H, Committee for the Standardization of Renal Pathological Diagnosis and for Renal Biopsy and Disease Registry in the Japanese Society of Nephrology. Membranous nephropathy in Japan: analysis of the Japan Renal Biopsy Registry (J-RBR). Clin Exp Nephrol. 2012;16:557-63.

Publisher's Note Springer Nature remains neutral with regard to jurisdictional claims in published maps and institutional affiliations. 